\title{
Scientific literacy of undergraduate chemistry students in the University of the West Indies, Barbados: individual and joint contributions of age, sex and level of study
}

\author{
Leah Garner-O'Neale ${ }^{1, *}$, Jelisa Maughan ${ }^{1}$, Babalola Ogunkola ${ }^{2, \star *}$ \\ ${ }^{1}$ Department of Biological and Chemical Sciences, Faculty of Science and Technology, \\ The University of the West Indies, Cave Hill Campus, Barbados \\ ${ }^{2}$ School of Education, Faculty of Humanities and Education, \\ The University of the West Indies, Cave Hill Campus, Barbados \\ ${ }^{*, * * E-m a i l ~ a d d r e s s: ~ l e a h . g a r n e r-o n e a l e @ c a v e h i l l . u w i . e d u ~, ~}$ \\ babalola.ogunkola@cavehill.uwi.edu
}

\begin{abstract}
The purpose of this study was two-fold. Firstly, to determine the level of scientific literacy of Chemistry undergraduate students at The University of the West Indies, Cave Hill Campus and secondly to investigate the individual and joint contributions of sex, age and level of study to the level of scientific literacy of the students. A total of one hundred and one (101) Chemistry undergraduate students from across the preliminary, $1^{\text {st }}, 2^{\text {nd }}$ and final years, participated in the study. The instrument chosen for this investigation, was the Basic Scientific Literacy Questionnaire (BSLQ) developed by Richard Carrier in 2001, which consisted of twenty-four (24) 'True' and 'False' questions. The instrument was found to be reliable with Crombach Alpha value of 0.6. The contributions of the variables sex, age range and level of study to the level of scientific literacy, were also analyzed and these were done via Independent Sample t-tests, Analysis of Variance (ANOVA) and linear regression. A confidence level of $95 \%$ was the set level for all of the analyses conducted. It was found that overall, the Chemistry undergraduate students are at a 'Good' level of scientific literacy. There were no statistically significant differences in the level of scientific literacy based on age range and level of study. However, sex was found to have contributed most and significantly to variations in the level of scientific literacy of the undergraduate chemistry students.
\end{abstract}

Keywords: scientific literacy; students of chemistry; University of the West Indies

\section{INTRODUCTION}

The term, 'scientific literacy', was first articulated as a goal of science education by Paul Hurd, in his 1958 article entitled, 'Science Literacy: Its Meaning for American Schools'( Hurd, 1958; Hurd,1998). Although, a few years prior in 1952, James Conant had used the phrase in an article entitled 'General Education in Science', he used it to express the idea of a general understanding of science. He however did not expand on its meaning, as Hurd had expounded in the near future (Bybee, 1997). The concept of 'scientific literacy' has cultural 
roots which date back to the introduction of modern science to Western civilization in the sixteenth century (Hurd, 1998). Renowned science philosopher of that time Francis Bacon, saw the paramount importance of science to human existence. He noted that science education was for the betterment and progress of persons, enabling them to apply the fundamental knowledge about tools utilized in science via purposeful inquiry through critical thinking and analysis, to all spheres of life (Hurd, 1998). This became the foundational purpose of being scientifically literate. Thus, scientific literacy became the term used to express the broad and encompassing purpose of science education (Bybee, McCrae, \& Laurie, 2009).

Scientific literacy is multifaceted. Some have suggested that being scientifically literate, is merely a matter of using science, rather than doing science. This view is reinforced by the many references made to scientific literacy, as what the average citizen ought to know about science (Laugksch, 2000;Hazen, 2002; Ogunkola, 2013). Hazen (2002) identified scientific literacy to be "a mix of concepts, history and philosophy that helps you understand the scientific issues of our time". Miller(2007) presented his interpretation of the phrase as "the level of understanding of science and technology needed to function in a modern industrial society". He further went on to state that the definition implied a minimal threshold level of understanding, rather than an ideal level of understanding (Hobson, 2008). Another definition put forward is that scientific literacy is:

"An individual's scientific knowledge and use of that knowledge to identify questions, to acquire new knowledge, to explain scientific phenomena, and to draw evidence based conclusions about science-related issues, understanding of the characteristic features of science as a form of human knowledge and enquiry, awareness of how science and technology shape our material, intellectual, and cultural environments, and willingness to engage in science-related issues, and with the ideas of science, as a reflective citizen"(Cresswell \& Vayssettes, 2006).

Despite the many definitions formulated for this popular catchphrase, there is still no unified consensus on a unitary meaning (Holbrook \& Rannikmae, 2009; Laugksch, 2000; Ogunkola, 2013). This is said to be attributed to the frequent re-conceptualization of the phrase, in order to keep up with the dynamic nature of science, as research and new discoveries are constantly being made in understanding the natural world (Ogunkola, 2013). However, it is universally agreed that scientific literacy is vitally important because science and technology permeates every facet of life. In discussing scientific literacy, there are a number of factors which have to be considered in order to provide a holistic view of this far reaching topic. These include the various components of scientific literacy, the levels of scientific literacy as well as the themes involved in achieving scientific literacy.

\section{COMPONENTS OF SCIENTIFIC LITERACY}

The three major components of scientific literacy are the scientific knowledge, knowledge of the nature of science, and methods of science. Scientific knowledge refers to what an individual knows of science and about science itself. 'Knowledge of science' includes understanding fundamental scientific concepts (such as facts, laws, theories, definitions, etc.) as they relate to the natural world; whereas knowledge about science involves understanding inquiry and the nature of scientific explanations (Bybee, et al., 2009).

The knowledge of the nature of science, allows one to understand and explain the interactions observed and experienced within the natural world. It includes all of the key 
principles and ideas which provide a description of science as a way of knowing through the process of inquiry. Below are the seven characteristics of science depicting what nature of science is (Parker, Krockover, Lasher-Trapp, \& Eichinger, 2008; Sterling, et al., 2010):

1. Scientific knowledge is tentative.

2. Scientific knowledge is empirically based.

3. Scientific knowledge is subjective.

4. Scientific knowledge is a product of the scientist's imagination and creativity.

5. Scientific knowledge is a product of observation and inference.

6. Scientists use a variety of methods in conducting scientific investigation and generating knowledge.

7. Scientific knowledge is socially and culturally embedded.

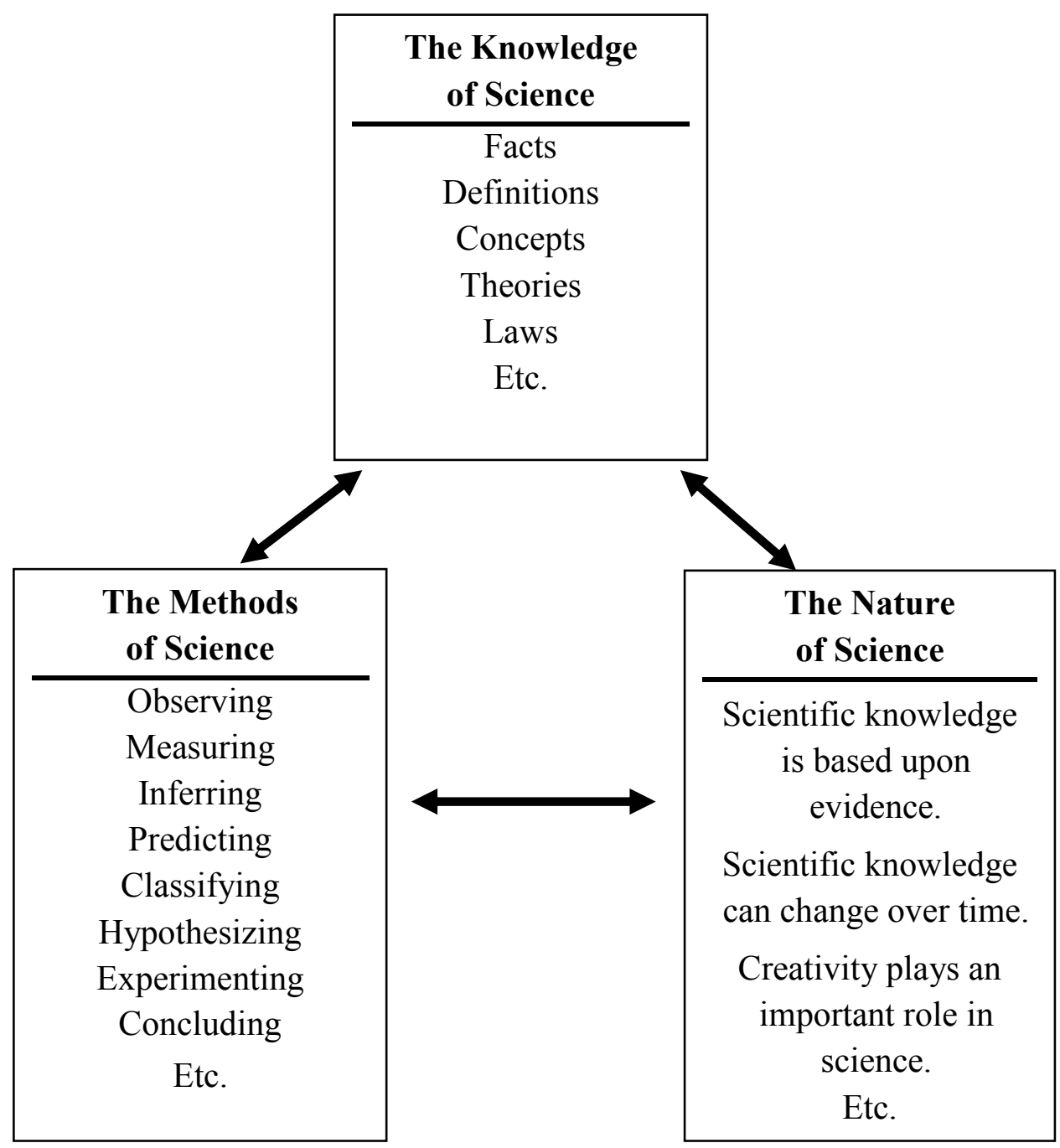

Figure 1. Three components of Scientific Literacy.

Source: Virginia Mathematics and Science Coalition, 2010.

The methods of science refer to the diverse procedures scientist use to formulate and generate scientific knowledge (Sterling et al, 2010). These procedures vary for each branch of science as scientist utilize the methods which best suit their investigation. A combination of 
methods is sometimes used and this can include observation, meaning, experimentation, clarifying and analyzing just to name a few.

\section{RATIONALE FOR THIS STUDY}

Being literate scientifically is essential to all, in order to actively participate civically, politically and socially, within a world being continuously shaped by science and technology (UNESCO, 1994). This theme coincides with the mission statement of the University of the West Indies (UWI) expressed in the strategic plan 2012-2017, which states that:

"The enduring mission of the UWI is:

To advance education and create knowledge through excellence in teaching, research, innovation, public service, intellectual leadership and outreach in order to support the inclusive (social, economic, political, cultural, environmental) development of the Caribbean region and beyond." (UWI, 2012)

This vision for the University's general education programme can be extended, and seen to incorporate the quest for scientific literacy. With this view in mind, the theme of science and its interaction with technology and society becomes more prominent. There is no denying the invaluable contribution which science and its many products have made to the evolution of mankind and the world in which they live. From the discovery and synthesis of drugs to the production of pest resistant crops, science has always held a pertinent usefulness to society (Bybee, et al., 2009; Holbrook \& Rannikmae, 2009).

Hence the importance of citizens being scientifically literate, as they would be able to understand and formulate informed opinions on global topics such as food security, genetic engineering, renewable energy systems, climate change and space exploration just to name a few. On a front closer to the home, the Caribbean too has a part to play in addressing these issues, in an effort to become a more developed region.

Through education, it has been making strides to produce scientifically literate individuals within our region, who are competent and ably equipped to address various scientifically based societal problems. From the secondary school level to the university level, increasing emphasis is being placed on cultivating successful crops of scientifically literate persons.

In spite of all this, are the fruits which are being produced as a result of this valiant effort ripe? Or is there a failing grade when it comes to whether the undergraduate chemistry students are scientifically literate or not?

It is therefore against this back drop, that research investigating the level of scientific literacy among Chemistry students at the undergraduate level, at The University of the West Indies Cave Hill Campus was conducted.

The following questions guided this study:

1. What is the overall level of scientific literacy of undergraduate Chemistry students?

2. Is there any significant difference in the level of scientific literacy of Chemistry undergraduate students based on their:
a. Sex?
b. Level of study?
c. Age? 
3. To what extent do sex, level of study and age jointly contribute to the students' level of scientific literacy?

4. What is the individual contribution of each of the variables: sex, level of study and age, to the students' level of scientific literacy?

\section{METHODOLOGY}

This research sought to investigate and determine the level of scientific literacy of Undergraduate Chemistry students at the University of the West Indies Cave Hill Campus. Descriptive survey research design was employed in carrying out the study. The target population included all the chemistry students in the University of the West Indies.

A total of thirty-five (35) Chemistry undergraduate students were chosen at random from the preliminary, $1^{\text {st }}, 2^{\text {nd }}$ and final years to participate in the pilot study. Of the 35 students, twelve (12) were males and twenty-three (23) were females. For the actual study one hundred and one (101) participants were selected using stratified random sampling from across the preliminary, $1^{\text {st }}, 2^{\text {nd }}$ and final years, with seventy-four (74) of this total being female and twenty-seven (27) being male.

The instrument selected to carry out this study, was the twenty-four (24) 'True' or 'False' item Basic Scientific Literacy Questionnaire (BSLQ) developed by Richard Carrier (Carrier, 2001). The questions were based on the three components of scientific literacy. The final questionnaire which was adopted to be administered to the participants, consisted of two sections, Section A and Section B.

The former section was designed to compile essential demographic information which included sex, age, level of study; while the latter section was the actual BSLQ. The items required students to place a tick $(\checkmark)$ in the column labeled ' $T$ ' if they thought that the statement was true, or a tick in the column labeled ' $\mathrm{F}$ ' if they found the statement to be false.

\section{1. The Pilot Study - Validity and Reliability of the Instruments}

A total of thirty-five (35) Chemistry undergraduate students were chosen at random from the preliminary, $1^{\text {st }}, 2^{\text {nd }}$ and final years to participate in the pilot study. Of the 35 students, twelve (12) were males and twenty-three (23) were females. Pilot studies are very important in determining the feasibility and appropriateness of a study and the proposed research instrument to be used (van Teijlingen \& Hundley, 2001). They can indicate problems such as complexity or ambiguity of questions, which can lead to unfavorable and misleading results in the main study.

This pilot study was done so as to identify and correct any vague or unclear questions, as well as determine the reliability and internal consistency of the questions. Reliability refers to the consistency and reproducibility of the results of the instrument being used (Leacock, Warrican \& Rose, 2009). Whereas the internal consistency, relates to the extent to which all of the items on the instrument measure the same concept and are related to each other (Tavakol \& Dennick, 2011).

This programme measured the internal consistency by calculating the Cronbach's Alpha for the items.Cronbach's Alpha is a common index of reliability used in Social Science research and as such, it was utilized in this study. This alpha coefficient, indicates the internal consistency of a test or scale being used and helps determine how closely related the items are as a collective set, thus substantiating the reliability of the test or scale. It is expressed as a 
number between 0 and 1. However, aCronbach's Alpha coefficient between $0.6 \geq 0.9$ is usually accepted.

The Cronbach's Alpha reliability coefficient calculated for the Basic Scientific Literacy Questionnaire was 0.556 which can be approximated to 0.6.

Although this value was slightly below it was deemed acceptable, since the removal of any of the questions would not significantly improve the alpha value further and the instrument consisted of only twenty-four (24) questions, thus it was used as is.

\section{2. The Actual Study}

There were one hundred and one (101) participants from across the preliminary, $1^{\text {st }}, 2^{\text {nd }}$ and final years, with seventy-four (74) of this total being female and twenty-seven (27) being male.

\section{3. Scoring, Ranking of Scientific Literacy Level and Data Analysis}

All data collected from the study was analyzed using Predictive Analytic Software (PASW) 18. The items on the BSLQ were scored using ' 1 ' for each correct answer and ' 0 ' for each incorrect answer.

The number of correct answers were tallied and expressed as a total out of twenty-four. In addressing research question 1, these frequencies were analyzed and then used to create a rating system for the overall level of scientific literacy for each student. A score between 0-6 was assigned 'Very Poor', 7-12 'Poor', 13-18 'Good' and 19-24 'Very Good'.

Moving onto research question 2, Independent Sample t-tests were performed to identify if there were any significant differences in the level of scientific literacy of the chemistry students, based on their age range (16-20 and 21 \& over) and sex (male and female).

This t-test was performed as it is the appropriate analysis to be done, when comparing two means. Any significant difference due to level of study (preliminary, $1^{\text {st }}, 2^{\text {nd }}$ and final years) was also analyzed and this was done by way of performing the One-way ANOVA test. Linear regression was done in answering research questions and 4 , in order to determine the extent to which the factors sex, age and level of study, both collectively and individually, contributed to the students' level of scientific literacy.

A $95 \%$ confidence level was the set level used in all statistical analyses. All data and information acquired from the questionnaires were held in confidence. Further analysis of the results was done and a comprehensive discussion and conclusion of the findings was made.

\section{RESULTS \& DISCUSSION}

\section{1. Demographics}

The demographic data (sex, age range and level of study) collected from the 101 questionnaires were analyzed and the results are shown in Tables 1, 2 and 3 below: 
Sex

Table 1. Distribution of Sex Among Undergraduate Chemistry Students at the UWI, Cave Hill Campus.

\begin{tabular}{|ccc|}
\hline Sex: & Frequency: & Percentage (\%): \\
\hline Male & 27 & 26.7 \\
\hline Female & 74 & 73.3 \\
\hline Total & 101 & 100 \\
\hline
\end{tabular}

The above table shows that there is a $46.6 \%$ difference between the number of females and males who participated in this study. These results clearly indicate that more females participated, as they accounted for $73.3 \%$ of the total 101 respondents, while males accounted for $26.7 \%$. This disparity is not surprising as the University as a whole, has a larger female student population (70\%) when compared to the male student population (30 \%) (UWI, 2013). These figures also totally invalidate the opinion expressed by Koshland in 1988 when he stated that 'Women are dramatically under-represented in university science and mathematics faculties...'(Linn \& Hyde, 1989) However, this vast difference in sex distribution has absolutely no bearing on the level of scientific literacy which either sex may possess.

\section{Age Range}

Table 2. Distribution of AgeAmong Undergraduate Chemistry Students at the UWI, Cave Hill Campus.

\begin{tabular}{|ccc|}
\hline Age Range: & Frequency: & Percentage (\%): \\
\hline $16-20$ & 68 & 67.3 \\
\hline $21 \&$ Over & 33 & 32.7 \\
\hline Total & 101 & 100 \\
\hline
\end{tabular}


Table 2 above shows that $67.3 \%$ of the respondents were between the ages of 16 and 20, while $32.7 \%$ were of ages 21 and above. On the analysis of age distribution among the Chemistry undergraduate students (Table 2), it shows that a large percentage of the students, both male and female, are between the ages of 16 and 20 years old, with the lesser percentage being 21 years and older. The 16-20 age range comprised of students from the preliminary, $1^{\text {st }}$ and $2^{\text {nd }}$ year levels, with one respondent from this group being in final year. The distribution of year level among the undergraduate chemistry students is shown in the table below.

\section{Level of Study}

Table 3. Distribution of Level of StudyAmong Undergraduate Chemistry Students at the UWI, Cave Hill Campus.

\begin{tabular}{|ccc|}
\hline Level of Study: & Prequency: & \\
\hline & 21 & 20.8 \\
\hline Preliminary & 52 & 51.5 \\
\hline $1^{\text {st }}$ Year & 12 & 11.9 \\
\hline The & & \\
\hline $2^{\text {nd }}$ Year & 16 & 15.8 \\
\hline Final Year & 101 & 100 \\
\hline Total & 16 & \\
\hline
\end{tabular}

The above Table 3 highlights that the greatest number of respondents came from the $1^{\text {st }}$ year $(51.5 \%)$, followed by the preliminary year $(20.8 \%)$, the final year $(15.8 \%)$ and lastly the $2^{\text {nd }}$ year $(11.9 \%)$. The $1^{\text {st }}$ year level having the greatest proportion was expected, as it comprises of students who have Chemistry as either a major or minor, as well as students who are required to take level one chemistry courses as prerequisites for majors such as Biochemistry, Biology, Microbiology and Ecology.

This level also comprises of students who are entering the University's Biological and Chemical Sciences Department for the first time and those moving up from the preliminary level. The distribution of students decreased for $2^{\text {nd }}$ and final years, as students are now allowed to choose what courses they wish to take at these respective levels, thus the classes to which the questionnaires were distributed at these levels would contain a lesser number of students compared to the $1^{\text {st }}$ year class. 


\section{2. Level of Scientific Literacy}

Table 4 and Figure 2 below depict the frequencies and the overall percentages of level of scientific literacy of undergraduate Chemistry students at The UWI, Cave Hill Campus. (Research question 1).

Table 4. Score, Rating \& Frequency of Level of Scientific Literacy.

\begin{tabular}{|c|c|c|c|c|c|c|}
\hline Score & Rating & $\begin{array}{c}\text { Rating } \\
\text { Description }\end{array}$ & Frequency & Percent & $\begin{array}{c}\text { Valid } \\
\text { Percent }\end{array}$ & $\begin{array}{c}\text { Cumulative } \\
\text { Percent }\end{array}$ \\
\hline $0-6$ & 1 & Very Poor & 3 & 3.0 & 3.0 & 3.0 \\
\hline $7-12$ & 2 & Poor & 41 & 40.6 & 40.6 & 43.6 \\
\hline $13-18$ & 3 & Good & 57 & 56.4 & 56.4 & 100.0 \\
\hline $19-24$ & 4 & Very Good & 0 & 0 & 0 & \\
\hline & & Total & 101 & 100.0 & 100.0 & \\
\hline
\end{tabular}

\section{Percentages \& Rating of Scientific Literacy of Undergraduate Chemistry Students}

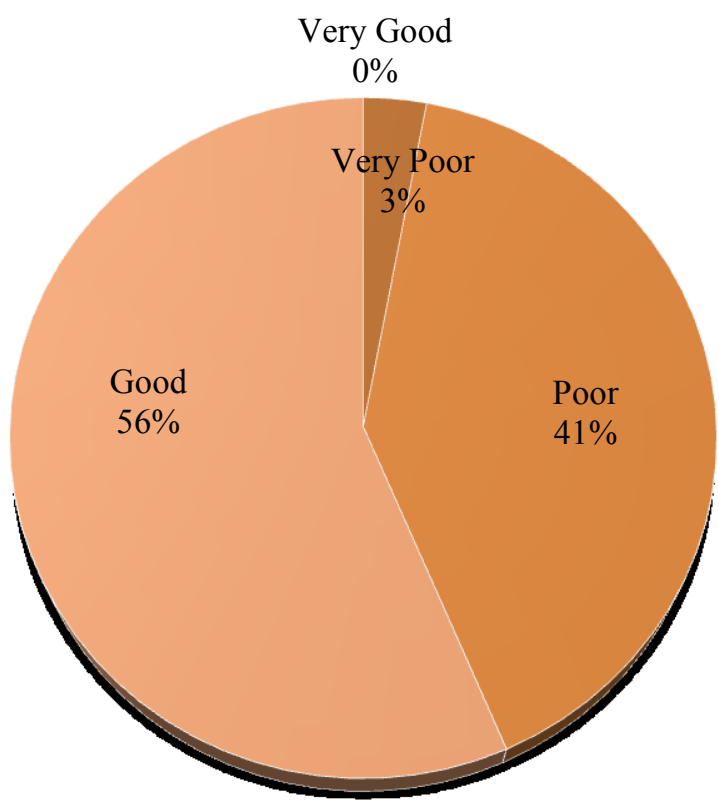

Figure 2. The Levels of Scientific Literacy Among Undergraduate Chemistry Students at the UWI, Cave Hill Campus. 
In assessing the level of scientific literacy, a value of 1 was assigned to scores in the range of 0-6 and this was described as 'Very Poor'. Scores between 7 and 12 were assigned a value of 2 and described as 'Poor', while a score falling in the range of 13-18 was designated a value of 3 and this was denoted as 'Good'.

The highest score range was 19-24 and this was represented by the value 4 and carried a description of 'Very Good'. The majority of students fell into the category of 'Good' which had a percentage of $56 \%$, more than half of the total 101 respondents. The second largest rating was 'Poor' and this had a percentage of 41 , while 'Very Poor' accounted for $3 \%$. The latter results were somewhat surprising as one would assume that students taking science courses would have acquired, at minimum, a good level of scientific literacy.

However, it must be taken into consideration that the BSLQ used in this study was based solely on the nature of science, which is just one of the three main components of scientific literacy.

This essential component of scientific literacy enables students to understand and interact with science as a way of generating knowledge and as an enterprise.(Abd-El-Khalick, 2012) Thus, it is important for students to have a firm grasp and comprehension of the nature of science, in order to effectively engage in scientific processes and practices. It could therefore be assumed that those students in the lower bracket may be deficient in this particular component of scientific literacy.

None of the students attained a rating of 'Very Good' which indicates that there is room for improvement in reaching the highest level of scientific literacy as it relates to the nature of science.

\section{3. Differences in the Level of Scientific Literacy}

After identifying the levels of scientific literacy of the students, the question of if there is any significant difference in the level of scientific literacy based on the variables sex, age and level of study, was investigated. (Research question 2)

Males had a higher mean score of 13.44 compared to the females, who had a mean score of 12.00. The females' mean score automatically places them at the 'Poor' level of scientific literacy, while the males are seen to be at the 'Good' level (Table 4).

To determine if there was any significant difference in the level of scientific literacy due to sex, an Independent Sample t-test was performed and the results showed that although there was only a difference of 1.44 between the males' and females' mean score, it was enough to cause a statistically significant difference in the level of scientific literacy based on sex $(\mathrm{t}=$ $2.51, \mathrm{p}=0.014)$.

These results obviously corroborate the time old adage about males doing better in science than females. For quite some time there has been continuous study and debate over gender differences in science based on attitude, achievement, interest, motivation and performance (Ogunkola \& Garner-O'Neale, 2013).

However, in recent times, studies have shown that these differences are minimal and decreasing and are only seen in some special cases (Amelink, 2009).

There is also the notion that females are sorely under-represented in pure and applied sciences and engineering, but again, this view is contradicted as there were almost three times as many females when compared to males in the chemistry students surveyed, as shown in Table 5. 
Table 5. Comparison of the Distribution of Level of Scientific Literacy based on Sex.

\begin{tabular}{|c|c|c|c|cc|}
\hline Sex & N & Mean & $\begin{array}{c}\text { Std. } \\
\text { Deviation }\end{array}$ & \multicolumn{2}{|c|}{ Std. Error } \\
Mean df \\
\hline Females & 74 & 12.000 & 2.638 & 0.307 & 99 \\
\hline Males & 27 & 13.444 & 2.309 & 0.444 \\
\hline
\end{tabular}

\section{4. Age Range}

In continuing the investigation into if there is any significant difference in level of scientific literacy based on age range was another variable considered and analyzed. The results are shown in Tables 7 and 8 below.

Table 6. Comparison of the Distribution of Level of Scientific Literacy based on Age Range.

\begin{tabular}{|c|c|c|c|c|c|}
\hline & $\begin{array}{c}\text { Age } \\
\text { Range }\end{array}$ & $\mathbf{N}$ & Mean & $\begin{array}{c}\text { Std. } \\
\text { Deviation }\end{array}$ & $\begin{array}{c}\text { Std. Error } \\
\text { Mean }\end{array}$ \\
\hline Total SL & $16-20$ & 68 & 12.382 & 2.528 & 0.306 \\
\cline { 2 - 6 } & $21-25$ & 33 & 12.394 & 2.850 & 0.496 \\
\hline
\end{tabular}

Comparison of the means given in Table 6, shows there is a minute mean difference of 0.012 between the mean scores of the two age ranges. The results of the t-test indicated that statistically, there is no significant difference in the level of scientific literacy based on age range $(\mathrm{t}=0.021, \mathrm{p}=0.984)$.

\section{5. Level of Study}

The final variable analyzed in determining any significant difference in the level of scientific literacy was the level of study of the students. The results of this analysis are shown in Table 7. 
Table 7. Comparison of the Distribution of Level of Scientific Literacy based on Level of Study.

\begin{tabular}{|c|c|c|c|c|c|c|c|c|}
\hline & \multirow{2}{*}{$\mathrm{N}$} & \multirow{2}{*}{ Mean } & \multirow{2}{*}{$\begin{array}{c}\text { Std. } \\
\text { Deviation }\end{array}$} & \multirow{2}{*}{$\begin{array}{l}\text { Std. } \\
\text { Error }\end{array}$} & \multicolumn{2}{|c|}{$\begin{array}{l}95 \% \text { Confidence Interval } \\
\text { for Mean }\end{array}$} & \multirow{2}{*}{ Minimum } & \multirow{2}{*}{ Maximum } \\
\hline & & & & & $\begin{array}{l}\text { Lower } \\
\text { Bound }\end{array}$ & $\begin{array}{l}\text { Upper } \\
\text { Bound }\end{array}$ & & \\
\hline Preliminary & 21 & 11.905 & 2.914 & 0.636 & 10.578 & 13.231 & 6.00 & 17.00 \\
\hline 1st Year & 52 & 12.385 & 2.328 & 0.323 & 11.737 & 13.033 & 6.00 & 16.00 \\
\hline 2nd Year & 12 & 12.833 & 3.010 & 0.869 & 10.921 & 14.746 & 7.00 & 18.00 \\
\hline Final year & 16 & 12.687 & 2.983 & 0.746 & 11.098 & 14.277 & 6.00 & 16.00 \\
\hline Total & 101 & 12.386 & 2.623 & 0.261 & 11.868 & 12.904 & 6.00 & 18.00 \\
\hline
\end{tabular}

Table 8. Significance of the Level of Scientific Literacy based on Level of Study.

\begin{tabular}{|c|c|c|c|c|c|}
\hline \multicolumn{7}{|c|}{ ANOVA } \\
\hline & $\begin{array}{c}\text { Sum of } \\
\text { Squares }\end{array}$ & df & $\begin{array}{c}\text { Mean } \\
\text { Square }\end{array}$ & F & Sig. \\
\hline $\begin{array}{c}\text { Between } \\
\text { Groups }\end{array}$ & 8.719 & 3 & 2.906 & 0.415 & 0.743 \\
\hline $\begin{array}{c}\text { Within } \\
\text { Groups }\end{array}$ & 679.221 & 97 & 7.002 & & \\
\hline Total & 687.941 & 100 & & & \\
\hline
\end{tabular}

On analysis of the results in Table 7, there is a gradual increase in the mean score from preliminary year $(11.90)$ to $1^{\text {st }}$ year 12.38$)$ to $2^{\text {nd }}$ year $(12.83)$. This trend lends to the notion that the level of scientific literacy increases as level of study increases. However, in moving from $2^{\text {nd }}$ year to final year, there is a slight decrease in the mean score by 0.146 . The results of the ANOVA test show that there is no significant difference statistically, in the level of scientific literacy due to level of study of the students $(F=0.415, p=0.743)$.

One might assume that as students progressed through the successive levels of study, they would increase in their level of scientific literacy as well, but this is not the case here as seen in Table 8.

This then raises the question of what may be the cause of this stagnation in level of scientific literacy, with respect to the nature of science. Some suggest that teaching with the nature of science, is enough to enlighten students to the concepts of nature of science; whereas teaching about the nature of science through formal instruction, enables students to develop an understanding of how scientific knowledge is generated and validated and allows them to recognize and appreciate the nature of this resultant knowledge. 
To remedy this defect which science students seem to have as it relates to the nature of science, a reformation of the science education curriculum has been the suggested balm.

This comes in light of the recognition that there is, 'the need to make nature of science instruction an integrated and meaningful component of science teaching...'(Abd-El-Khalick, 2012).

\section{6. Contribution of Sex, Age and Level of Study to Level of Scientific Literacy}

An attempt was made to determine the combined and individual contribution of each of the variables (sex, age and level of study) to the students' level of scientific literacy. The results of the regression analysis are shown in Tables 9 and 10 below.

Table 9. Collective Contribution of Sex, Age and Level of Study on the Level of Scientific Literacy.

\begin{tabular}{|c|c|c|c|c|c|}
\hline & Ad & $\begin{array}{l}=0.2 \\
=0 . \\
\text { d } R^{2} \\
\text { f the }\end{array}$ & mate $=2$ & & \\
\hline \multicolumn{6}{|c|}{ ANOVA } \\
\hline Model & $\begin{array}{l}\text { Sum of } \\
\text { Squares }\end{array}$ & df & $\begin{array}{c}\text { Mean } \\
\text { Square }\end{array}$ & $\mathbf{F}$ & Sig. \\
\hline Regression & 45.077 & 3 & 15.026 & 2.267 & 0.086 \\
\hline Regression & 642.863 & 97 & 6.627 & & \\
\hline Total & 687.941 & 100 & & & \\
\hline
\end{tabular}

Table 10. Relative Contribution of Sex, Age and Level of Study to the Level of Scientific Literacy.

\begin{tabular}{|c|c|c|c|c|c|}
\hline \multirow{2}{*}{ Model } & \multicolumn{2}{|c|}{ Unstandardized Coefficients } & \multirow{2}{*}{$\begin{array}{c}\begin{array}{c}\text { Standardized } \\
\text { Coefficients }\end{array} \\
\text { Beta }\end{array}$} & \multirow{2}{*}{ t } & \multirow{2}{*}{ Sig. } \\
\hline & B & Std. Error & & & \\
\hline (Constant) & 10.395 & 1.079 & & 9.633 & 0.000 \\
\hline Sex & 1.379 & 0.585 & 0.234 & 2.356 & 0.021 \\
\hline Age Range & -0.200 & 0.606 & -0.036 & -0.329 & 0.743 \\
\hline Level of Study & 0.228 & 0.301 & 0.083 & 0.758 & 0.451 \\
\hline
\end{tabular}


Based on results presented in Table 9, it is seen that there is a slight correlation with a positive but negligible relationship between the three variables, as collectively, sex, age range and level of study contributed to $6.6 \%$ of the overall variance observed $\left(R^{2}=0.066, p=\right.$ 0.086). Results also indicate that the three variables do not significantly predict the levels of scientific literacy of the students $(F=2.267, p=0.086)$. On analysis of the individual contributions (Table 10), sex is the highest direct contributor and significantly so $(\beta=0.234, p$ $=0.021)$. The next contributor is level of study, as this too had a direct relationship, although it was not significant $(\beta=0.083, p=0.451)$. Age range was seen to be the least contributing factor, with an insignificant indirect relationship $(\beta=-0.036, p=0.743)$.

\section{CONCLUSION}

In this study, it was found that the majority of Chemistry undergraduate students at The University of the West Indies, Cave Hill Campus, are at a 'Good' level of scientific literacy. Statistics showed that there was a significant difference in the level of scientific literacy based on sex, with males being the more scientifically literate. However, there was no significant difference statistically, in the level of scientific literacy based on age range and the level of study. It was also determined that sex, age range and level of study collectively, did not significantly predict the scientific literacy level, as there was a slight correlation with a positive but negligible relationship, which existed between the three variables.

\section{References}

[1] Abd-El-Khalick F., Teaching With and About Nature of Science, and Science Teacher Knowledge Domains. Science \& Education (2012) 1-21.

[2] Amelink C. (2009). Literature overview: Gender differences in science achievement. SWE-AWE CASEE Overviews.

[3] Bybee R., McCrae B., Laurie R., Journal of Research in Science Teaching 46(8) (2009) 865-883.

[4] Bybee R. W. (1997). Achieving Scientific Literacy: From Purposes to Practices (1 ed.): Heinemann.

[5] Carrier R. (2001, 16 February, 2013). The Internet Infidels Test of Scientific Literacy Retrieved February, 2013, from http://www.infidels.org/library/modern/richard_carrier/SciLit.html

[6] Chabalengula V. M., Mumba F., Lorsbach T., Moore C., Curriculum and instructional validity of the scientific literacy themes covered in Zambian high school biology curriculum. International Journal of Environmental \& Science Education 3(3) (2008)

[7] Cresswell, J., \& Vayssettes, S. (2006). Assessing scientific, reading and mathematical literacy: a framework for PISA 2006: Organisation for Economic Cooperation and Development (OECD).

[8] CXC. (2006). Caribbean Advanced Proficiency Examinations Chemistry Syllabus.

[9] Dilevko J., Gottlieb L., The Journal of Academic Librarianship 28(6) (2002) 381-392. 
[10] Hazen R. M. (2002). Why should you be scientifically literate. ActionBioscience. org.

[11] Hobson A., The Physics Teacher 46 (2008) 404.

[12] Holbrook J., Rannikmae M. (2009). International Journal of Environmental \& Science Education 4(3) (2008) 275-288.

[13] Hurd P. D., Educational Leadership 16(1) (1958) 13-16.

[14] Hurd P. D., Science education 82(3) (1998) 407-416.

[15] Laugksch R. C. (2000). The Differential Role of Physical Science and Biology in Achieving Scientific Literacy in South Africa--A Possible Explanation.

[16] Laugksch R. C., Science education 84(1) (2000) 71-94.

[17] Leacock C., Warrican S., Rose G. (2009). Research methods for inexperienced researchers. Kingston Jamaica: Ian Randle Publishers.

[18] Linn M. C., Hyde J. S., Educational Researcher 18(8) (1989) 17-27.

[19] Lombardi V. (2005). Beyond the Quote - Motivational Success Quotes and Quotations Retrieved 17th April, 2013, from:

http://beyondthequote.com/success-quotes.html

[20] Ogunkola B. J., Journal of Educational and Social Research 3(1) (2013) 9.

[21] Ogunkola B. J., Garner-O’Neale L. Mediterranean Journal of Social Sciences 4(1) (2013) 9.

[22] Oliver J. S., Jackson D. F., Chun S., Kemp A., Tippins D. J., Leonard R., Rascoe B., Electronic Journal of Literacy through Science 1(1) (2001) 1-33.

[23] Parker L. C., Krockover, G. H., Lasher-Trapp, S., Eichinger, D. C., Bull. Am. Meteorol. Soc. 89 (2008) 1681-1688.

[24] Sterling D. R., Aitken, K., Schools F. C. P., Berube C., Calhoun J., Schools P. W. C. P., Hagan, D. B. (2010). Virginia Mathematics and Science Coalition Scientific Inquiry and the Nature of Science Task Force Report.

[25] Tavakol M., Dennick R., International Journal of Medical Education 2 (2011) 53-55.

[26] UNESCO. (1994). Science and Technology for All: Project 2000+.

[27] UWI. (2002). FOUN 1210-Science, Medicine \& Technology in Society Course Material.

[28] UWI. (2012). The University of the West Indies Strategic Plan 2012-2017 (pp. 44):

Office of Planning and Development.

[29] UWI. (2013). International Office- International Students: FAQs Retrieved 2nd April, 2013, from http://www.cavehill.uwi.edu/international/intl/faqs.asp

[30] van Teijlingen E., Hundley V., Social research update (35) (2001) 1-4. 